\title{
Urgensi Manajemen Kelas Pada Pendidikan Dasar
}

\author{
Masriani $^{1}$, Istikomah ${ }^{2}$ \\ ${ }^{1}$ Pendidikan Guru Madrasah Ibtidaiyah, STAI Auliaurrasyidin, Tembilahan Riau, Indonesia \\ ${ }^{2}$ Pendidikan Anak Islam Usia Dini, IAI Yasni, Bungo Jambi, Indonesia \\ *Corresponding author: riani.muhammadsyah@gmail.com \\ *Corresponding author: istidani88@gmail.com
}

\begin{abstract}
Abstrak
Guru adalah sebuah profesi. Profesionalitas guru tentunya sangat terkait denganmanajemen kerja guru dalam membuat perencanaan, yang kemudian mengaplikasikanya dengan mengajar dikelas,pengelolaan kelas adalah penyediaan fasilitas bagi bermacam-macam kegiatan belajar siswa dalam lingkungan sosial, emosional, dan intelektual dalam kelas. Fasilitas yang disediakan itu memungkinkan siswa belajar dan bekerja, terciptanya suasana sosial yang memberikan kepuasan, suasana disiplin, perkembangan intelektual, emosional dan sikap serta apresiasi pada siswa, inti dari pengelolaan kelas adalah menyeimbankan pengelolaan siswa dan pengelolan fasilitas.
\end{abstract}

Kata kunci: Manjemen, Kelas, Pendidikan, Dasar

\section{PENDAHULUAN}

Sekolah sebagai institusi (lembaga) pendidikan merupakan wadah tempat proses pendidikan dilakukan, memiliki sistem yang komplek dan dinamis. Dalam kaitannya, sekolah adalah tempat yang bukan hanya sekedar tempat berkumpul guru dan murid, melainkan berada pada suatu tatanan yang rumitdan saling berkaitan. Oleh karena itu sekolah di pandang suatu organisasi yang membutuhkan pengelolaan lebih dari itu.Kegiatan lain organisasi sekolah adalah mengelola sumber daya manusia (SDM) yang diharapkan menghasilkan lulusan yang berkualitas sesuai dengan tuntutan kebutuhan masyarakat serta pada gilirannya lulusan sekolah diharapkan dapat memberikan kontribusi kepada pembangunan bangsa.

Penempatan kualitas sumber daya manusia sebagai penentu baik dalam konteks pembangunan nasional maupun dalam tatanan peradaban global merupakan dua sisi dari suatu perubahan, perlumenempatkan pendidikan sebagai sentral yang harus dipertahankan oleh semua pihak yang terlibat 
Pendidikan Sekolah Dasar mempunyai manfaat sebagai berikut : 1. Dengan pendidikan Sekolah Dasar diharapkan anak dapat bersosialisasi dengan lingkungannya sehingga akan terbentuk kepribadiannya, kapasitas intelektualnya dan kepekaan sosialnya. b. Dengan pendidikan Sekolah Dasar diharapkan dapat menyiapkan anak untuk melanjutkan pendidikan ke jenjang yang lebih tinggi sehingga pada jenjang inilah diharapkan anak-anak telah mampunyai bekal yang cukup untuk bisa melanjkutakan ke jenjang pendidikan berikutnya. c. Jika mereka tidak melanjutkan ke jenjang berikutnya, paling tidak mereka telah memiliki bekal pengetahuan dan ketrampilan yang dapat membantu mencari pekerjaan. ${ }^{1}$.

Tujuan pendidikan Dasar adalah mengacu Undang-Undang Sistem Pendidikan Nasional UUSPN No. 20 Tahun 2003, pada Peraturan Pemerintah pasal 3 Nomor 28 Tahun 1990 tujuan pendidikan Sekolah Dasar adalah :

1. Mendidik murid agar menjadi manusia Indonesia seutuhnya berdasarkan pancasila yang mampu membangun dirinya sendiri dan ikut bertanggungjawab terhadap pembangunan bangsa.

2. Memberikan bekal kemampuan yang diperlukan bagi murid untuk melanjutkan pendidikan ke tingkat yang lebih tinggi atau ke jenjang selanjutnya.

3. Memberikan bekal kemampuan dasar untuk hidup di masyarakat dan mengembangkan diri sesuai dengan bakat, minat dan kemampuan serta lingkungan. Berdasarkan uraian tujuan pendidikan di Sekolah Dasar maka dapat dijelaskan bahwa pendidikan Sekolah Dasar bertujuan memberikan bekal kemampuan dasar pada siswa untuk melanjutkan pendidikan ke jenjang yang lebih tinggi guna mengembangkan kehidupan pribadi, anggota masyarakat, dan warga negara

Kualitas pembelajaran tidak hanya ditentukan oleh pembaharuan kurikulum,fasilitas yang tersedia, kompetensi guru dan beberapa kemampuan lainnya, namun tak kalah pentingnya dalam mewujudkan kualitas pembelajarn adalah kemampuan guru menguasai kiat kiat manajemen kelas, keadaan kelas yang sering kali tak terkendali, terlebih pada lembaga lembaga pendiikan dasar, maka tugas gurulah menciptakan dan mempertahankan kondisi kelas yang dapat menguntungkan bagi peserta didik.

Peranan guru sebagai manajer dalam kegiatan belajar di kelas sudah lama diakui sebagai salah satu faktor yang penting dalam meningkatkan prestasi belajar siswa. Guru sebagai tenaga profesional, dituntut tidak hanya mampu mengelola pembelajaran saja tetapi juga harus mampu mengelola kelas, yaitu menciptakan dan mempertahankan kondisi belajar yang optimal bagi tercapainya tujuan pengajaran. Oleh karena itu sejalan dengan upaya pemerintah dalam meningkatkan mutu di semua jenjang pendidikan, penerapan strategi pengelolaan kelas dalam pembelajaran merupakan salah satu alternatif yang diyakini dapat digunakan untuk memecahkan persoalan yang mendasar dari permasalahan pendidikan di tanah air. peranan guru dalam proses belajar mengajar

${ }^{1}$ Suryosubroto Manajemen Sekolah Dasar.(Yogyakarta: Fakultas Ilmu Pendidikan (FIP) UNY,2007) hlm 5. 
adalah sebagai berikut: (a) guru sebagai demonstrator, (b) guru sebagai pengelola kelas, (c) guru sebagai mediator dan fasilitator dan (d) guru sebagai evaluator.

Guru adalah sebuah profesi. Profesionalitas guru tentunya sangat terkait dengan manajemen kerja guru dalam membuat perencanaan, yang kemudian mengaplikasikanya dengan mengajar dikelas. Lalu harus ada evaluasi tentang kualitas pembelajaran.

Oleh karena itu, demi harapan kemajuan kualitas pendidikan guru di Indonesia, hendaknya untuk menjadi guru profesional adalah memiliki kemauan untuk selalu belajar dalam meningkatkan siswa yang berkualitas. Dengan belajar mengelola kelas sebaik-baiknya yang ditinjau dari pendekatan pembelajaran berupa strategi, metode, maupun model pembelajaran yang tepat dalam penyampaian materi pelajaran, akan menghasilkan siswa yang berkualitas baik the best input maupun the best proses.

Persyaratan utama yang harus dipenuhi bagi berlangsungnya proses pembelajaran yang efektif dan efisien ialah tersedianya pendidik yang mampu memenuhi pengelolaan kelas yang efektif. Pengelolaan kelas merupakan masalah tingkah laku yang kompleks, dan pendidik harus mampu menciptakan kondisi kelas yang sedemikian rupa sehingga proses pembelajaran dapat berjalan dengan baik dan bermutu. Kualitas proses dan hasil pembelajaran yang optimal diperlukan guru atau dosen yang mampu mengelola kelas. Salah satu indikator yang menyatakan bahwa pendidik yang profesional adalah memiliki kemampuan mengelola kelas, yaitu menyediakan suasana yang kondusif untuk berlangsungnya proses pembelajaran yang efektif dan efisien. Apabila belum kondusif maka seorang pendidik harus berupaya seoptimal mungkin untuk menguasai, mengatur dan membenahi, serta menciptakan suasana kelas yang kondusif sehingga proses pembelajaran dapat berjalan secara optimal untuk mencapai tujuan pembelajaran yang diinginkan.

Pendidik dengan pemahaman psikologi pendidikan yang memadai memungkinkan untuk dapat menciptakan iklim sosio-emosional yang kondusif di dalam kelas, sehingga peserta didik dapat belajar dengan nyaman dan menyenamgkan. Suasana kelas yang kondusif dan optimal dalam proses pembelajaran dapat tercapai jika pendidik mampu mengatur peserta didik dan sarana prasarana pembelajaran untuk mencapai tujuan belajar mengajar serta dapat mengatasi masalah-masalah yang timbul di dalam kelas.

Masalah pokok yang dihadapi guru, baik pemula maupun yang sudah berpengalaman adalah pengelolaan kelas. Aspek yang paling sering didiskusikan oleh penulis profesional dan oleh para pengajar adalah juga pengelolaan kelas. Mengapa demikian? Jawabnya sederhana. Pengelolaan kelas merupakan masalah tingkah laku yang kompleks, dan guru menggunakannya untuk menciptakan dan mempertahankan kondisi kelas sedemikian rupa sehingga anak didik dapat mencapai tujuan pengajaran efisien dan menggunakan mereka dapat belajar. Dengan demikian pengelolaan kelas yang efektif adalah syarat bagi pengajaran yang efektif. Tugas utama dan paling sulit bagi guru adalah pengelolaan kelas, lebih-lebih tidak ada satu pun pendekatan yang dikatakan paling baik.

Gairah proses belajar dan semangat pencapaian prestasi belajar yang tinggi, amat tergantung pada pembiasaan sehari-hari atas kehidupan yang terjadi di antara guru dan 
para anak didiknya di dalam kelas. Karena itu manajemen atau pengelolaan atas kelas merupakan hal utama dalam menunjang terciptanya proses belajar yang menyenangkan dan pencapaian prestasi belajar yang tinggi itu. Kondisi dan kehidupan kelas kita di tingkat pendidikan dasar, khususnya pada Madrasah Ibtidaiyah.

Penampilan fisik kelas yang anak-anak tinggali setiap harinya nampak kurang kondusif atas penciptaan kondisi belajar yang diinginkan. Meja, kursi atau bangku yang mereka duduki kurang sesuai dengan kebutuhan belajar mereka. Kebiasaan bersih, indah dan tertib dalam membuang sampah belum terciptakan dari dalam kelas secara kuat. Kelas-kelas kita di antaranya masih belum asri, bahkan semrawut dan kotor. Sentuhan tangan untuk penataan kelas dari orang-orang yang berkepentingan atas pendidikan anak amat terbatas.

Masa usia sekolah dasar sebagai mesa kanak-kanak akhir yang berlangsung dari usia enam tahun hingga kira-kira usia sebelas tahun atau dua belas tahun. Karakteristik utama siswa sekolah dasar adalah mereka menampilkan perbedaan-perbedaan individual dalam banyak segi dan bidang, di antaranya, perbedaan dalam intelegensi, kemampuan dalam kognitif dan bahasa, perkembangan kepribadian dan perkembangan fisik anak.

\section{KAJIAN KONSEP MANAJEMEN KELAS}

Pengelolaan kelas terdiri dari dua kata yaitu "pengelolaan" dan"kelas". Pengelolaan itu sendiri akar katanya adalah "kelola", ditambahawalan "pe" dan akhiran "an". Pengelolaa dalam pengertian umum adalah pengadministrasian, pengaturan atau penataan suatu kegiatan. 2 Menurut E. Mulyasa, pengelolaan kelas merupakanketerampilan guru untuk menciptakan iklimpembelajaran yang kondusif,dan mengendalikannya jika terjadi gangguan dalam pembelajaran. ${ }^{3}$

Jika mencermati beberapa studi tentang manajemen kelas dari beberapa referens iilmiah maka dapat diketahui bahwa konsep manajemen kelas disamakan denagan pengelolaan kelas yaitu penciptaan suasana dan kondisi kelasyang memungkinkan siswa dalam kelas tersebut belajar dengan efektif. ${ }^{4}$

Adapun pengertian pengelolaan kelas juga terdapat beberapapendapat, diantaranya:

1. Menurut Made Pidarta, pengelolaan kelas ialah proses seleksi dan

penggunaan alat-alat yang tepat terhadap problem dan situasi kelas. Iniberarti guru bertugas menciptakan, memperbaiki dan memeliharasistem/organisasi kelas sehingga anak didik dapat memanfaatkankemampuannya, bakatnya, dan energinya pada tugastugas individual. ${ }^{5}$

2.MenurutSudirman N., pengelolaan kelas ialah upaya mendayagunakanpotensi kelas.6

\footnotetext{
${ }^{2}$ Syaifurahman, Manajemen dalam Pembelajaran (Jakarta: PT. Indeks, 2013), hal.50.

${ }^{3}$ E. Mulyasa, Menjadi Guru Profesional (Bandung: Rosda Karya, 2005), hal 91.

${ }^{4}$ Imam Gunawan, Manajemen Kelas tiori dan aplikasinya(Depok:PT RajaGrafindo Persada, 2019) hal 8 .

${ }^{5}$ Made Pidarta, Pengelolaan Kelas (Surabaya: Usaha Nasional, tt.).

${ }^{6}$ Sudirman, Ilmu Pendidikan (Bandung: Remaja Rosdakarya, 1991), hal 310.
} 
4. Menurut Suharsimi Arikunto, pengelolaan kelas ialah suatu usaha yangdilakukan oleh penanggung jawab kegiatan belajar mengajar atau yangmembantu dengan maksud agar dicapai kondisi optimal sehingga dapatterlaksana kegiatan belajar seperti yang diharapkan. ${ }^{7}$ Suharsimimemahami pengelolaan kelas ini dari dua segi yaitu pengelolaan yangmenyangkut siswa dan pengelolaan fisik.Menurutnya membuka jendelaagar udara segar dapat masuk ke ruangan atau agar ruangan menjadi terang, menyalakan lampu listrik, menggeser papan tulis, mengatur mejamerupakan kegiatan pengelolaan kelas secara fisik.

5. Menurut AJE Toenlioe, pengelolaan kelas adalah usaha guru untukmenciptakan dan mempertahankan kondisi yang memungkinkankegiatan pengelolaan pembelajaran dapat berlangsung dengan lancar sehingga tujuan pembelajaran dapat tercapai. ${ }^{8}$

6. Menurut Muljani A. Nurhadi, pengelolaan kelas adalah upaya mengelolasiswa di kelas yang dilakukan untuk menciptakan dan mempertahankansuasana (kondisi) kelas jalan menciptakan dan mempertahankan motivasi siswa untuk selalu terlibat dan berperan serta dalam proses pendidikan di sekolah. ${ }^{9}$

Maka pengeloalan kelas adalah penyelenggaraan sistem pembelajaran yang sangat komplek dan mendasar, dapat di lihat dari usaha-usaha menciptakan suasana kegiatan pembelajaran yang kondusif dan mencapai kondisi optimal untuk kepentingan pembelajaran. Jika mengacu pada proses manajemen, maka manajemen kelas juga memilki proses yaitu perencanaan,pelaksanaan dan pengawasan yang dilakukan oleh guru baik individu maupun melalui orang lain .

Jika mengacu pada konteks diataas maka tugas guru dalam manajemen kelas adalah menciptakan, memperbaikidan memelihara stabilitas kemampuan belajar siswa, bakat dan energi yang dimiliki.

\section{Tujuan dan prinsip-prinsip manajemen kelas}

Menurut Dirjen Dikdasmenn 1996 tujuan dari manajemen kelas adalah mewujudkan suasana pembelajaran yang efektif dan menyenangkan serta dapat memotivasi ssiwabelajar dengan baik sesuai dengan kemampuannya. 10 Manajemen kelas adalah ketentuan dan prosedur yang diperlukan guna menciptakan dan memelihara lingkungan tempat terjadi kegiatan belajar dan mengajar.Manajemen kelas juga dapat diartikan sebagai perangkat perilaku dan kegiatan guru yang diarahkan untuk menarik perilaku siswa yang wajar, pantas, dan layak serta usaha dalam meminimalkan gangguan. ${ }^{11}$

\section{a. Tujuan manajemen kelas.}

Tujuan pengelolaan kelas pada hakikatnya telah terkandung dalam tujuan pendidikan.Secara umum tujuan pengelolaan kelas adalah penyediaan fasilitas bagi bermacam-macam kegiatan belajar siswa dalam lingkungan sosial, emosional, dan

\footnotetext{
${ }^{7}$ SuharsimiArikunto, Pengelolaan Kelas dan Siswa Sebuah Pendekatan Evaluatif(Jakarta: Rajawali Press, 1988), hal 67.

${ }^{8}$ AJE Toenlioe, Teori dan Praktek Pengelolaan Kelas (Surabaya: Usaha Nasional, 1991), hlm16. hlm 162.

${ }^{9}$ Muljani A. Nurhadi, Administrasi Pendidikan di Sekolah (Yogyakarta: Andi Offset, 1983),

${ }^{10} \mathrm{Op}$, Cit Imam Gunawan, hlm17

${ }^{11}$ Hasri, Salfen. . Sekolah Efektif dan Guru Efektif.(Yogyakarta: Aditya Media Printing and Publising..2009) hlm 41.
} 
intelektual dalam kelas. Fasilitas yang disediakan itu memungkinkan siswa belajar dan bekerja, terciptanya suasana sosial yang memberikan kepuasan, suasana disiplin, perkembangan intelektual, emosional dan sikap serta apresiasi pada siswa ${ }^{12}$

Tujuan manajemen kelas adalah sebagai berikut:

1) Agar pengajaran dapat dilakukan secara maksimal sehingga tujuan pembelajaran dapat dicapai efektif dan efesien

2) Untuk memberi kemudahan dalam usaha memantau kemajuan siswa dalam pelajarannya. Dengan Manajemen Kelas, guru mudah untuk melihat dan mengamati setiap kemajuan/ perkembangan yang dicapai siswa, terutama siswa yang tergolong lamban.

3) Untuk memberi kemudahan dalam mengangkat masalah-masalah penting untuk dibicarakan dikelas demi perbaikan pengajaran pada masa mendatang. ${ }^{13}$

Sedangkan menurut Mudasir, tujuan manajemen kelas atau pengelolaan adalah sebagai berikut

1. Mewujudkan situasi dan kondisi kelas, baik sebagai lingkungan belajar maupun sebagai kelompok belajar.

2. Menghilangkan berbagai hambatan belajar yang dapat menghalangi terwujudnya kegiatan belajar.

3. Menyediakan dan mengatur fasilitas serta perabot belajar yang mendukung dan memungkinkan siswa belajar sesuai dengan lingkungan sosial, emosional, dan intelektual siswa di kelas.

4. Membina dan membimbing sesuai dengan latar belakang sosial, ekonomi dan budaya serta sifat individual. ${ }^{14}$

\section{b. Prinsip-prinsp manajemen kelas}

Secara umum faktor yang mempengaruhi manajemen kelas dibagi menjadi dua golongan yaitu, faktor intern dan faktor ekstern siswa). Faktor intern siswa berhubungan dengan masalah emosi, pikiran, dan perilaku.Kepribadian siswa denga ciri-ciri khasnya masing-masing menyebabkan siswa berbeda dari siswa lainnya sacara individual.Perbedaan sacara individual ini dilihat dari segi aspek yaitu perbedaan biologis, intelektual, dan psikologis.Faktor ekstern siswa terkait dengan masalah suasana lingkungan belajar, penempatan siswa, pengelompokan siswa, jumlah siswa, dan sebagainya. Masalah jumlah siswa di kelas akan mewarnai dinamika kelas. Semakin banyak jumlah siswa di kelas, misalnya dua puluh orang ke atas akan cenderung lebih mudah terjadi konflik. Sebaliknya semakin sedikit jumlah siswa di kelas cenderung lebih kecil terjadi konflik.menyebutkan "Dalam rangka memperkecil

\footnotetext{
${ }^{12}$ SyaifulBahri. Guru dan Anak Didik Dalam Interaksi Edukatif.(Jakarta: Rineka Cipta,2000)hlm178

${ }^{13}$ Wijaya, Cece dan Rusyan, A. Tabrani. Kemampuan Dasar Guru Dalam Proses Belajar Mengajar ( Bandung: Remaja Rosdakarya, 1194) hlm 55.

${ }^{14}$ Mudasir.. Manajemen Kelas. (Yogyakarta: Zanafa Publishing.2011) hlm 20.
} 
masalah gangguan dalam pengelolaan kelas dapat dipergunakan." Prinsip-prinsip pengelolaan kelas yang dikemukakan oleh Djamarah adalah sebagai berikut.

1. Hangat dan Antusias Hangat dan Antusias diperlukan dalam proses belajar mengajar. Guru yang hangat dan akrab pada anak didik selalu menunjukkan antusias pada tugasnya atau pada aktifitasnyaakan berhasil dalam mengimplementasikan pengelolaan kelas.

2. Tantangan Penggunaan kata-kata, tindakan, cara kerja, atau bahan-bahan yang menantang akan meningkatkan gairah siswa untuk belajar sehingga mengurangi kemungkinan munculnya tingkah laku yang menyimpang

3. .Bervariasi Penggunaan alat atau media, gaya mengajar guru, pola interaksi antara guru dan anak didik akan mengurangi munculnya gangguan, meningkatkan perhatian siswa. Kevariasian ini merupakan kunci untuk tercapainya pengelolaan kelas yang efektif dan menghindari kejenuhan

4. Keluwesan Keluwesan tingkah laku guru untuk mengubah strategi mengajarnya dapat mencegah kemungkinan munculnya gangguan siswa serta menciptakan iklim belajarmengajar yang efektif. Keluwesan pengajaran dapat mencegah munculnya gangguan seperti keributan siswa, tidak ada perhatian, tidak mengerjakan tugas dan sebagainya.

5. Penekanan pada Hal-Hal yang Positif Pada dasarnya dalam mengajar dan mendidik, guru harus menekankan pada hal-hal yang positif dan menghindari pemusatan perhatian pada hal-hal yang negative. Penekanan pada hal-hal yang positif yaitu penekanan yang dilakukan guru terhadap tingkah laku siswa yang positif daripada mengomeli tingkah laku yang negatif. Penekanan tersebut dapat dilakukan dengan pemberian penguatan yang positif dan kesadaran guru untuk menghindari kesalahan yang dapat mengganggu jalannya proses belajar mengajar.

6. Penanaman Disiplin Diri Tujuan akhir dari pengelolaan kelas adalah anak didik dapat mengembangkan dislipin diri sendiri dan guru sendiri hendaknya menjadi teladan mengendalikan diri dan pelaksanaan tanggung jawab. Jadi, guru harus disiplin dalam segala hal bila ingin anak didiknya ikut berdisiplin dalam segala hal. ${ }^{15}$

Menurur Muhaimin prinsip prinsip manajemen kelas sebagai berikut:

Dalam manajemen kelas terdapat beberapa prinsip yang harus diperhatikan sebagai prasyarat menciptakan satu model pembelajaranyang efektif dan efisien, yaitu

1. Prinsip Kesiapan (Readiness)

Kesiapan belajar ialah kematangan dan pertumbuhan fisik, psikis, inteligensi, latar belakang pengalaman, hasil belajar yang baku, motivasi, persepsi dan faktorfaktor lain yang memungkinkan seseorang dapat belajar.

2. Prinsip Motivasi (Motivation)

${ }^{15}$ Djamarah, SyaifulBahri. . Strategi Belajar Mengajar. (Rineka Cipta, Jakarta).hlm 184. 
Motivasi adalah tenaga pendorong atau penarik yang menyebabkan adanya tingkah laku ke arah suatu tujuan tertentu. Adanya motivasi pada peserta didik maka akan bersungguh-sungguh menunjukkan minat, mempunyai perhatian, dan rasa ingin tahu yang kuat untuk ikut serta dalam kegiatan belajar, berusaha keras dan memberikan waktu yang cukup untuk melakukan kegiatan tersebut serta terus bekerja sampai tugas-tugas tersebut terselesaikan.

3. Prinsip Perhatian .

Perhatian merupakan suatu strategi kognitif yang mencakup empat keterampilan yaitu berorientasi pada suatu masalah, meninjau sepintas isi masalah, memusatkan diri pada aspek-aspek yang relevan dan mengabaikan stimuli yang tidak relevan. Dalam proses pembelajaran perhatian merupakan faktor yang besar pengaruhnya. ${ }^{16}$

\section{c. Ruang lingkup manajemen kelas}

Ruang lingkup manajemen kelas merupakan suatunhal yang harus dipenuhi oleh setiap sekolah, hal ini untuk penunjang prestasi peserta didik.adapun klasifikasi ruang lingkup manajemen kelas adalah ruang lingkup kelas fisik dan non fisik. Ruang lingkup manajemen kelas fisik adalah berupa pengelolaan kelas yang memfokuskan padahal yang bersifat fisik, mencakup pengaturan peserta didik dalam belajar,ruang belajar, dan perabot kelas, ruang lingkup manajemen kelas non fisik berupa pegelolaan kelas yang memfokuskan pada asfek interaksi peseta didik denagn peserta didik lainnya, perserta didik dengan guru dan lingkungan kelaas dan sekolah sebelum ,selama dan setelah pembelajaran. ${ }^{17}$

Apabila manajemen dipandang sebagaisebuah proses maka ada beberapa kegiatan yang harus dijalankan guru, Wahyuningsih dalam gunawan menyatak kegiatan manajemen kelas yaitu pengaturan orang (siswa)dan pengaturan fasilitas. ${ }^{18}$

\section{Pengelolan siswa}

Siswa adalah makhluk hidup yang mempunya emosi, naluri kebutuhan serta karaakter yang berbeda .Dari keberagaman tersebut sangat memungkinkan terjadi perubahan prilaku siswa dari waktu ke waktu, tiba tiba siswa berprilaku diluar dugaan akan menyebabkan munculnya masalah masalah baru dalam proses pembelajaran maupun di luar pembelajaran.

Berikut ini di uraikan beberapa kegiatan pengaturan siswa;

Disini fungsi guru memiliki proporsi yang besar dalam rangka membimbing, mengarahkan, dan mengatur segala aktivitas yang dilakukan oleh peserta didik. Oleh karena itu pengaturan peserta didik adalah bagaimana mengatur dan menempatkan peserta didik di dalam kelas sesuai dengan potensi intelektual dan perkembangan emosionalnya. Dalam pengelolaan kelas kegiatan peserta didik meliputi:

1) Tingkah laku peserta didik

\footnotetext{
,2002)hlm 144

${ }^{16}$ Muhaimin. Paradigma Pendidikan Agama Islam.( Bandung: Remaja Rosyda Karya

${ }^{17}$ Op, cit, Imam Gunawan hlm 76.

${ }^{18}$ Ibid, Imam Gunawan hlm 77
} 
Tingkah laku adalah tindakan-tindakan yang dilakukan oleh peserta didik sesuai dengan nilai-nilai norma yang ada di dalam masyarakat yang sudah ada sebelumnya dalam suatu kelompok masyarakat.

2) Kedisiplinan peserta didik

Pelaksanaan pengelolaan kelas sangat erat kaitanya dengan kedisiplinan peserta didik. Kedisplinan pesserta didik akan terwujud dengan adanya aturan-aturan kelas yang menjadi standar bagi perilaku peserta didik.

3) Minat/perhatian peserta didik

Minat adalah suatu kecenderungan untuk memberikan perhatian dan bertindak terhadap orang, aktivitas atau situasi yang menjadi objek dari minat tersebut dengan disertai perasaan senang.

4) Gairah belajar peserta didik

Gairah belajar adalah aspek psikolgis seseorang yang menampakkan diri dalam beberapa gejala seperti semangat, keinginan perasaan, suka melakukan proses tingkah laku melalui berbagai kegiatan yang meliputi pengetahuan dan pengalaman.

5) Dinamika kelompok peserta didik

Dinamika kelompok adalah suatu kelompok yang terdiri dari dua atau lebih individu yang memiliki hubungan psikologis

secara jelas antara anggota satu dengan yang lain dan berlangsung dalam situasi yang dialami.

6) Kerjasama siswa

Sebagai makhluk sosial, kerjasama merupakan kebutuhan yang sangat penting artinya bagi kelangsungan hidup. Tanpa kerjasama, tidak akan ada individu, keluarga, organisasi atau sekolah.Dengan adanya kerjasama yang baik dalam pembelajaran, akan mempermudah pemahaman siswa dalam belajar. ${ }^{19}$

\section{Pengelolaan fasilitas}

Keberlangsunag semua aktivitas siswa di dalam kelas banyak dipengaruhi oleh kondisi dan situasi fisik lingkungan kelas, Pengaturan lingkungan belajar sangat diperlukan agar anak mampu melakukan kontrol terhadap pemenuhan kebutuhan emosionalnya. Lingkungan belajar yang memberi kebebasan kepada anak untuk melakukan pilihan-pilihan akan mendorong anak untuk terlibat secara fisik, emosional, dan mental dalam proses belajar, dan karena itu, akan dapat memunculkan kegiatankegiatan yang kreatif-produktif.

Salah satupengelolaan kelas adalah berkenaan denganpengaturan kondisi fisik siswa, hal inimerupakan bentukpengeklolaan dan pengaturan kelas yang berkaitan dengan ketatalaksanaan ruangan yang yang di batasi oleh dinding, tempat siswa berkumpul bersama mempelajari segala yang diberikan pengajar. ${ }^{20}$

Pengelolan lingkungan fisik meliputi beberapa hal sebagai berikut:

\section{a. Pengelolaan ruang belajar.}

Adapun prinsip-prinsip yang perlu diperhatikan oleh seorang guru dalam menata lingkungan fisik kelas adalah sebagai berikut :

1) Visibility ( Keleluasaan Pandangan)

${ }^{19}$ Ibid, Gunawan hlm 80.

${ }^{20}$ Ali Rohmad, Jurnal ilmiah Tarbiyah,Inovasi pengelolaan kelas dalam mengacu kedinamisan pembelajaran, Malang Universitas Negeri Malang hlm 356. 
Visibility artinya penempatan dan penataan barang-barang di dalam kelas tidak mengganggu pandangan siswa, sehingga siswa secara leluasa dapat memandang guru, benda atau kegiatan yang sedang berlangsung.Begitu pula guru harus dapat memandang semua siswa kegiatan pembelajaran.

2) Accesibility (mudah dicapai)

Penataan ruang harus dapat memudahkan siswa untuk meraih atau mengambil barang-barang yang dibutuhkan selama proses pembelajaran. Selain itu jarak antar tempat duduk harus cukup untuk dilalui oleh siswa sehingga siswa dapat bergerak dengan mudah dan tidak mengganggu siswa lain yang sedang bekerja.

3) Fleksibilitas (Keluwesan)

4) Barang-barang di dalam kelas hendaknya mudah ditata dan dipindahkan yang disesuaikan dengan kegiatan pembelajaran. Seperti penataan tempat duduk yang perlu dirubah jika proses pembelajaran menggunakan metode diskusi, dan kerja kelompok.

5) Kenyamanan

Kenyamanan disini berkenaan dengan temperatur ruangan, cahaya, suara, dan kepadatan kelas.

6) Keindahan

Prinsip keindahan ini berkenaan dengan usaha guru menata ruang kelas yang menyenangkan dan kondusif bagi kegiatan belajar. Ruangan kelas yang indah dan menyenangkan dapat berpengaruh positif pada sikap dan tingkah laku siswa terhadap kegiatan pembelajaran yang dilaksanakan. Selain seperti yang disebutkan diatas, sebaiknya guru juga mempertimbangan pula pada aspek biologis seperti, postur tubuh siswa, dimana menempatkan siswa yang mempunyai tubuh tinggi dan atau rendah. Dan bagaimana menempatkan siswa yang mempunyai kelainan dalam arti secara psikologis, misalnya siswa yang hiper aktif, suka melamun, dan lain sebagainya sehingga penataan lingkungan kelas dapat dikondisikan seefektif mungkin. ${ }^{21}$

b. Pengaturan tempat duduk

1.) Tradisional.

Formasi yang biasa kita temui dalam kelas kelas tradisional yang memungkinkanpara siswa untuk duduk berpasangan dalam satu meja dengan dua kursi.

${ }^{21}$ Udin S. Winataputra, Strategi belajar mengajar (Jakarta: Universitas Terbuka Departemen Penddidikan Nasional, 2003) hlm 22. 


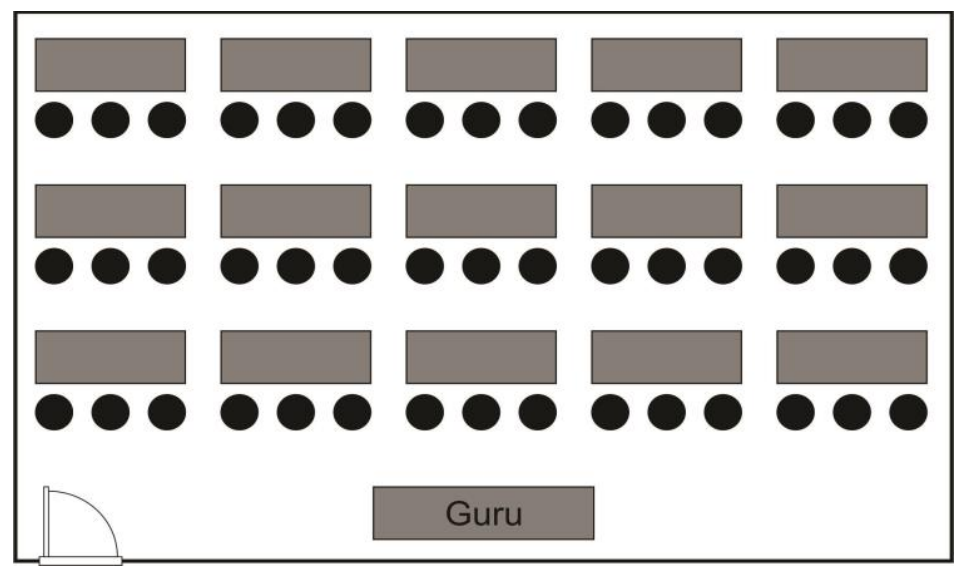

Gambar 1.Pola pengaturan tempat duduk tradisional

\section{2.) Formasi auditorium}

Bentuk auditorium menyediakan lingkungan yang sangat terbatas untuk belajar aktif, namun hal ini dapat dicoba untuk mengurangi kebosanan siswa yang terbiasa dalam penataan ruang secara konvesional (tradisional).Jika sebuah ruang kelas tempat duduknya dapat dengan mudah dipindah pindahkan, maka guru dapat membuat bentuk pembelajaran ala auditorium untuk membentuk hubungan yang lebih erat, sehingga memudahkan siswa. Formasi ini sering digunakan dinegara negara barat, disini pendidik akan menjadi pusat perhatian, biasanya jika menggunakan formasi auditorium ini guru menggunakan metode ceramah dan biasanya disertai tanya jawab yang sifatnya interaktif..

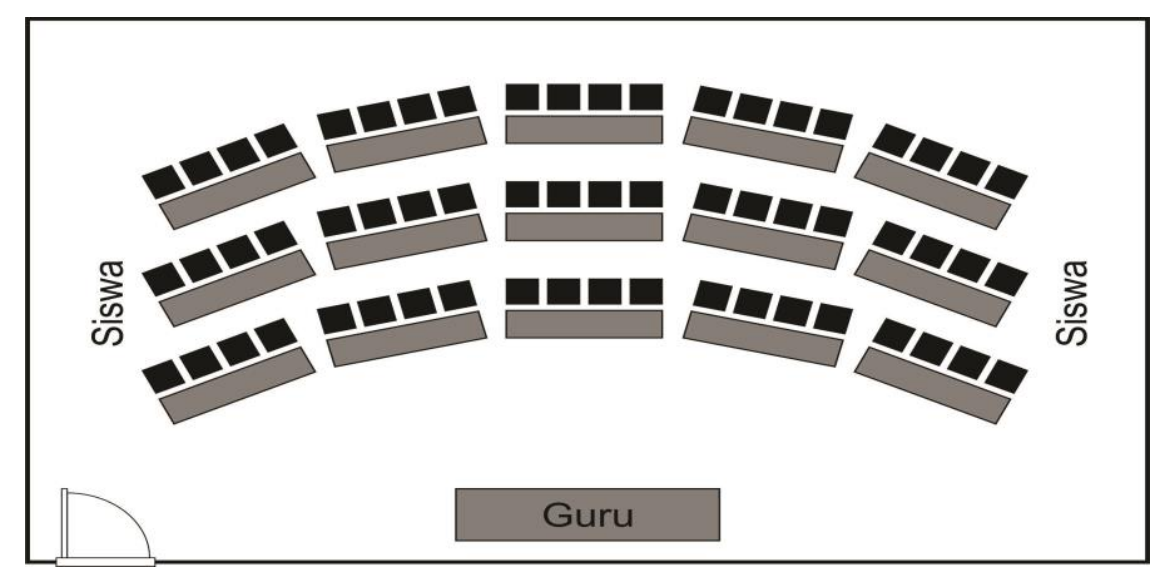

Gambar 2.Pola pengaturan tempat dudukformasi audotarium

3) Formasi kelas bentuk U

Formasi ini sangat menarik dan mampu mengaktifkan para siswa, sehingga mampu membuat mereka antusias untuk mengikuti pembelajaran.Disini guru yang paling aktif dengan bergerak dinamis kesegala arah dan langsung berinteraksi berhadap hadapan dengan mereka.jadi para siswa akan memaksimalkan indra mereka dan mengikuti pembelajaran sekaligus berinteraksi secara langsung, sehiongga akan 
mendapatkan respon daripendidik secara langsung.formasi ini bisa digunakan untuk memberi materi apapun, sehingga formasi $U$ ini menjadi multifungsi.

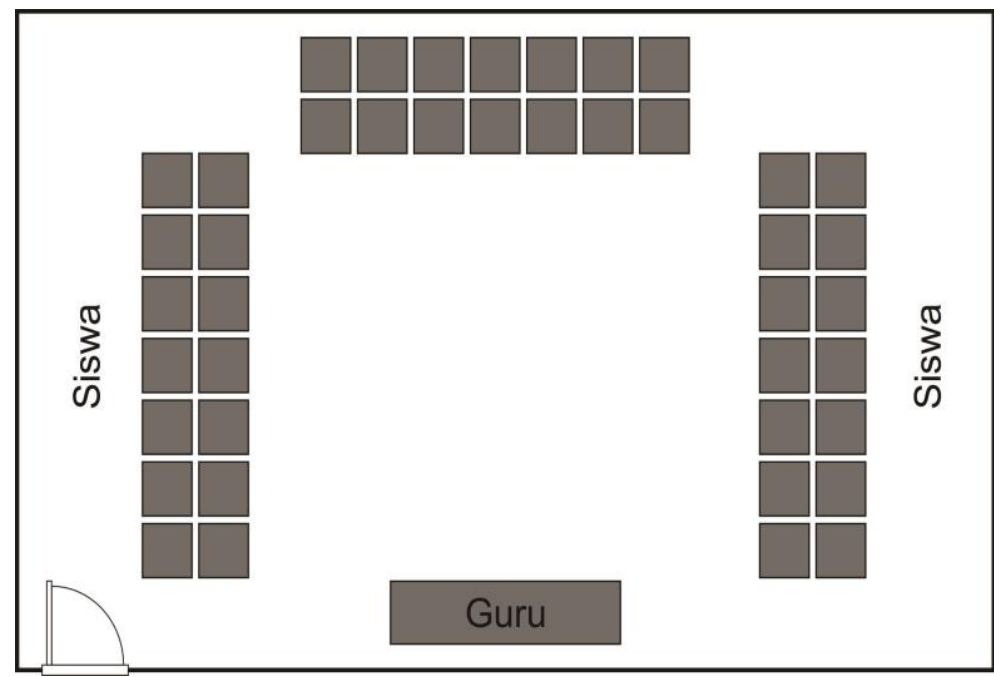

Gambar 3 Pola pengaturan tempat dudukformasi U

\section{4) Formasi konferensi}

Pada formasi ini meja yang harus digunakan adalah meja panjang yang didekatkan satu persatu dalam bentuk memanjang sehingga terbentuk kumpulan meja berbentuk persegi panjang. Kemudian para peserta didik duduk di kursi yang mengelilingi meja-meja persegi panjang tersebut.

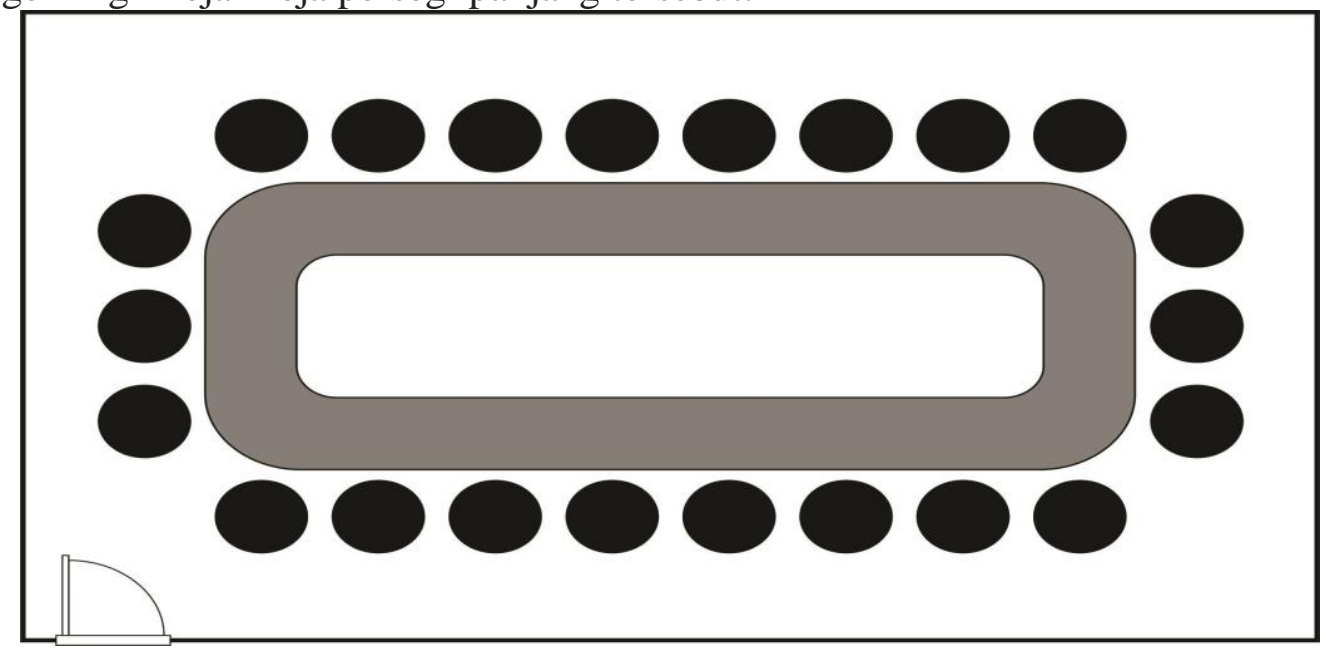

Gambar 4.Pola pengaturan tempat duduk meja pertemuan

5) Formasi pengelompokan terpisah/breakout Groupings.

Formasi pengelompokan terpisah dapat di lakukan dalam kelas yang cukup luas,guru dapat meletakkan meja meja dan kursi dimana kelompok kecil dapat melakukan aktivitas belajar yang di pecah menjadi beberapa tim, pecahzn kelompok tersebut di letakkan berjauhan sehingga tidak saling mengganggu, tetapi hendaknya dihindari penenmpatan ruangan kelompok yang berjauhan. 


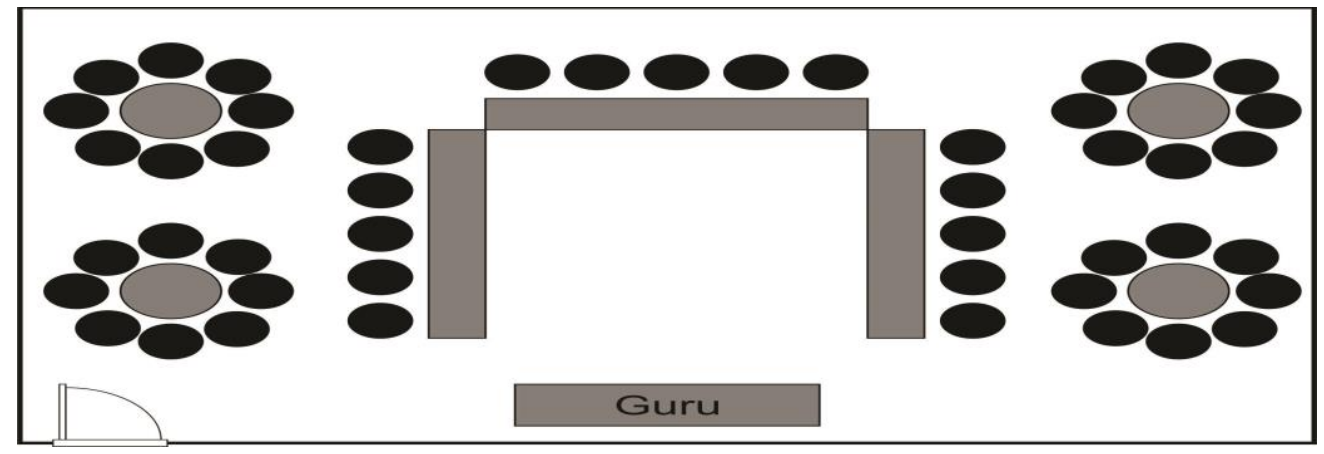

Gambar 5.Pola pengaturan tempat duduk pengelompokan terpisah

6) Formasi duduk erderet atay berbaris

Pengaturan tempat duduk seperti ini adalah tempat duduk yang paling populer, pada umumnya tempat duduk ini diatur menurut tinggi pendeknya siswa. Siswa yangtinggi duduk dibelakang sedangkan sisiwa yang pendek duduk didepan atau pada situasi tertentu contoh nya ada sisiwa yang tidak dapat melihat jarak jauh atau pendengaran nya kurang .

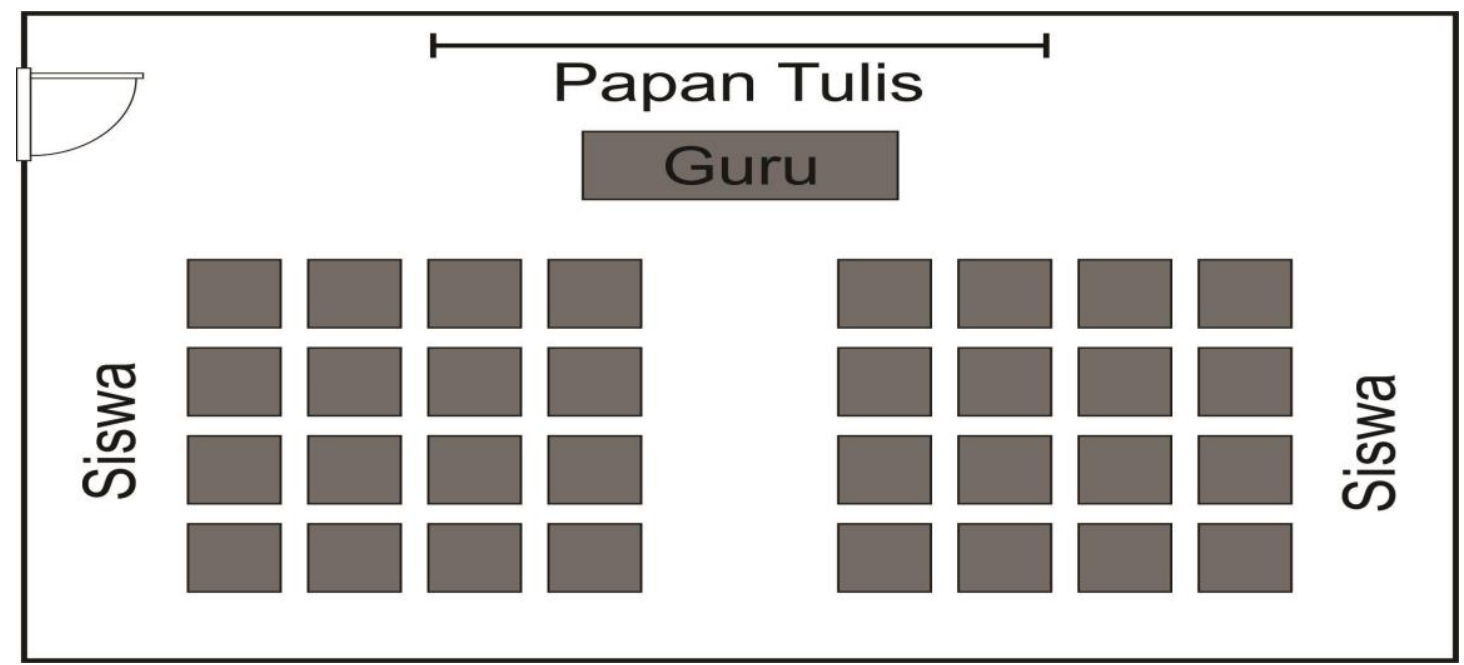

Gambar 6.Pola pengaturan tempat duduk berjejer atau berderet.

7) Formasi meja pertemuan.

Formasi ini dapat digunakan dengan cara membagi siswa kedalam beberapa kelompok, dimana setiap kelompok,dimana setiap kelompok tersebut mempunyai meja pertemuan nya sendiri-sendiri.Guru dapat memberikan tugas yang berbeda antar kelompok, guru dapat memantau aktivitas siswa setiap kelompok dengan berkeiing pada setiap kelompok saat mengerjakan tugas 


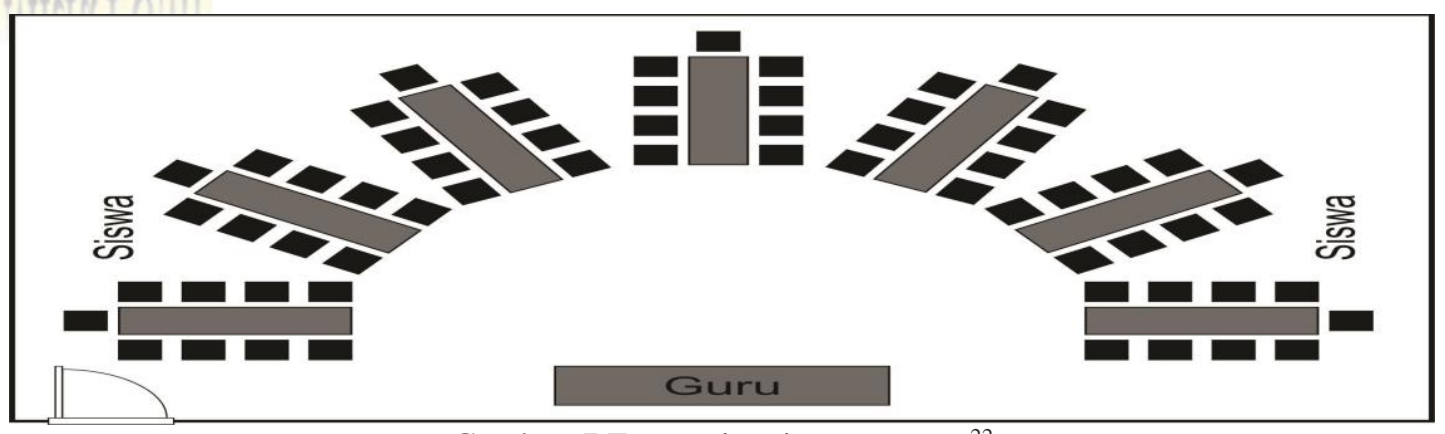

Gambar 7.Fotrmasi meja pertemuan. ${ }^{22}$

\section{c. Ventilasi dan pengaturan cahaya}

Ventilasi harus menjamin kesehatan peserta didik, Jendela harus cukup besar yang memungkinkan panas cahayamatahari masuk, udara sehat dengan ventilasi yang baik, pesertadidik harus dapat melihat tulisan dengan jelas, tulisan dipapan tulis, buku bacaan, pencahayaan harus cukup tapi tidak menyilaukan.

\section{KESIMPULAN DAN SARAN}

\section{Kesimpiulan}

Terus mengasah kemampuan sebagai pengelola kelss merupakan sebuah kewajiban seorang guru karena seorang guru harus memiliki kemampuan yang baik dalam mengelola kelas di jenjang pendidikan dasar, menyeimbangkan antara pengelolan siswa dan pengelolan fasilitas, kedua hal tersebut merupakan faktor pendukung utama dalam proses pembelajaran. Menyeimbangkan keduanya di leembaga pendidikan dasar bukan sesuastu yang mudah mengingat siswa siswi pada jenjang ini memiliki interaksi intertaksi istimewa di bandingkan siswa siswa di jenjang di atasnya.,

\section{Saran}

Sebagai guru dijenjang pendidikan dasar sebaiknya lebih mengutamakan aspek pengelolan sisiwa dengan membuat lingkungan belajar yang nyaman dengan memaksimalkan pengunaan fasilitas yang ada.

\section{DAFTAR PUSTAKA}

Ali Rohmad,Jurnal ilmiah Tarbiyah,Inovasi pengelolaan kelas dalam mengacu kedinamisan pembelajaran, Malang Universitas Negeri Malang

Djamarah, SyaifulBahri. 2015, Strategi Belajar Mengajar. Jakarta,Rineka Cipta E.

Mulyasa 2005, Menjadi Guru Profesional Bandung, Rosda Karya

Hasri, Salfenn 2011, Sekolah Efektif dan Guru Efektif.Yogyakarta, Aditya Media Printing and Publising.

Imam Gunawan 2019,Manajemen Kelas tiori dan aplikasinya Depok:PT RajaGrafindo Persada.

Made Pidarta, Pengelolaan Kelas Surabaya, Usaha Nasional

Mudasir 2011, Manajemen Kelas. Yogyakarta, Zanafa Publishing.

\footnotetext{
${ }^{22}$ Op.Cit, Gunawan, hal 101.
} 
Muhaimin 2002, Paradigma Pendidikan Agama Islam, Bandung: Remaja Rosyda Karya.

Muljani A. Nurhadi, Administrasi Pendidikan di Sekolah, Yogyakarta, Andi Offset. Rajawali Press.

Sudirman 2000, Ilmu Pendidikan , Bandung: Remaja Rosdakarya

Suryosubroto 2007,Manajemen Sekolah Dasar. Yogyakarta, Fakultas Ilmu Pendidikan (FIP) UNY..

SyaifulBahri2000, Guru dan Anak Didik Dalam Interaksi Edukatif, Jakarta, Rineka Cipta

Syaifurahman 2013, Manajemen dalam Pembelajaran Jakarta:, PT. Indeks.

Udin S. Winataputra 2013,Strategi belajar mengajar (Jakarta: Universitas Terbuka Departemen Penddidikan Nasiona

Wijaya, Cece dan Rusyan, A. Tabrani 2000. Kemampuan Dasar Guru Dalam Proses Belajar Mengajar, Bandung, Remaja Rosdakarya. 